\title{
First case of erysipelas in a free-ranging bottlenose dolphin (Tursiops truncatus) stranded in the Mediterranean Sea
}

\author{
Mar Melero ${ }^{1, *}$, Consuelo Rubio-Guerri ${ }^{1}$, Jose Luis Crespo ${ }^{1}$, Manuel Arbelo ${ }^{2}$, \\ Ana Isabel Vela ${ }^{1}$, Daniel García-Párraga ${ }^{3}$, Eva Sierra ${ }^{2}$, Lucas Domínguez ${ }^{1}$, José \\ Manuel Sánchez-Vizcaíno ${ }^{1}$ \\ ${ }^{1}$ VISAVET Center and Animal Health Department, Veterinary School, Complutense University of Madrid, 28040 Madrid, Spain \\ ${ }^{2}$ Unit of Histology and Veterinary Pathology, Institute for Animal Health, Veterinary School, \\ University of Las Palmas de Gran Canaria, 35416 Canary Islands, Spain \\ ${ }^{3}$ Veterinary Department, Oceanographic Aquarium of the Ciudad de las Artes y las Ciencias, 46023 Valencia, Spain
}

\begin{abstract}
An adult female bottlenose dolphin (Tursiops truncatus) stranded alive and subsequently died several minutes later on the Mediterranean coast of Spain on 14 July 2010. Clinical examination revealed foam through the blowhole and rales upon lung auscultation. On venipuncture, the blood was abnormally dense and dark. Hematological and biochemical abnormalities included dehydration, leukocytosis (48600 leukocytes $\mathrm{\mu l}^{-1}$ ) characterized by neutrophilia (48 200 neutrophils $\left.\mathrm{\mu l}^{-1}\right)$, and elevated bilirubin $\left(4.38 \mathrm{mg} \mathrm{dl}^{-1}\right)$, alanine aminotransferase $\left(382.3 \mathrm{U} \mathrm{l}^{-1}\right)$, aspartate aminotransferase $\left(1449.3 \mathrm{U} \mathrm{l}^{-1}\right)$, lactate dehydrogenase $\left(1631.3 \mathrm{U} \mathrm{l}^{-1}\right)$, and creatine kinase $\left(404.7 \mathrm{U} \mathrm{l}^{-1}\right)$. The most relevant findings of the gross examination were rhomboid-shaped skin lesions, stable froth in the trachea, pulmonary congestion, abnormally thick and rough pleura with adhesions, edematous and congestive superficial cervical and tracheobronchial lymph nodes, red-tinged urine, and severe brain congestion. Histopathology of the kidney, lung, skin, and brain revealed multisystemic intravascular bacterial emboli. Samples of skin, brain, and lung were cultured on Columbia blood agar under both aerobic and anaerobic conditions, and pure and heavy bacterial cultures were obtained from skin and brain samples. The microorganism isolated was Gram-positive, catalase-negative, facultatively anaerobic, and rod-shaped. The isolates were identified as Erysipelothrix rhusiopathiae by the API Coryne biochemical system. Based on the gross and microscopic findings, a diagnosis of acute E. rhusiopathiae septicemia was made. To the best of our knowledge, this is the first report of $E$. rhusiopathiae septicemia in a free-ranging bottlenose dolphin.
\end{abstract}

KEY WORDS: Erysipelothrix rhusiopathiae - Septicemia - Diamond-shaped skin lesions · Bottlenose dolphin · Tursiops truncatus

Resale or republication not permitted without written consent of the publisher

\section{INTRODUCTION}

Erysipelothrix rhusiopathiae is the only pathogenic species of the genus Erysipelothrix (Wang et al. 2010). This bacterium is a facultative anaerobe, nonspore-forming, non-acid-fast, small, Gram-positive, rod-shaped bacillus (Brooke \& Riley 1999, Wang et al. 2010). It is ubiquitous, can persist for long periods in the environment, including marine locations (Wang et al. 2010), has been isolated from the cutaneous slime of both fresh- and saltwater fish (Seibold \& Neal 1956, Lauckner 1985, Kinsel et al. 1997), and 
may persist on insects, mollusks, and crustaceans (Brooke \& Riley 1999, Wang et al. 2010).

Erysipelothrix rhusiopathiae is the causative agent of erysipelas, a disease of many mammalian and avian species, mainly swine and turkeys (Kinsel et al. 1997, Dunn et al. 2001, Wang et al. 2010). In humans, the disease caused by E. rhusiopathiae is known as erysipeloid to differentiate between the human streptococcal disease erysipelas (Brooke \& Riley 1999). Erysipeloid is considered an occupational zoonosis caused by contact with contaminated animals, especially while handling fish, their products, their wastes, or soil (Suer \& Vedros 1988, Hunt et al. 2008, Wang et al. 2010). Three forms of disease caused by E. rhusiopathiae infection have been described in humans: a localized cutaneous form, a generalized cutaneous form, and a septicemic form, which is associated with endocarditis (Wang et al. 2010). The dermatologic and acute septicemic forms have been reported in cetaceans: bottlenose dolphin Tursiops truncatus, spotted dolphin Stenella plagiodon, long-finned pilot whale Globicephala melas, Indo-Pacific bottlenose dolphin T. aduncus, white-beaked dolphin Lagenorhynchus albirostris, Pacific white-sided dolphin $L$. obliquidens, beluga whale Delphinapterus leucas, Risso's dolphin Grampus griseus, killer whale Orcinus orca, and harbor porpoise Phocoena phocoena (Seibold \& Neal 1956, Chastel et al. 1975, Thurman et al. 1983, Buck \& Spotte 1986, Kinsel et al. 1997, Young et al. 1997, pers. comm., Boseret et al. 2002, pers. comm.). If untreated, the septicemic form often results in death in humans (Wang et al. 2010) and animals (Suer \& Vedros 1988). The pathognomonic sign of erysipelas in many species is the presence of diamond-shaped skin lesions (Wang et al. 2010). In cetaceans, the lesions appear as gray, elevated rhomboid plaques with well-defined edges that occur over the entire body (Thurman et al. 1983, Suer \& Vedros 1988, Kinsel et al. 1997, Dunn et al. 2001, Boseret et al. 2002, pers. comm.). Erysipelas is rarely encountered in pinnipeds and is not considered a clinical problem (Lauckner 1985, Suer \& Vedros 1988, Dunn et al. 2001), whereas cetaceans are the marine mammals most susceptible to the disease (Suer \& Vedros 1988, Higgins 2000).

In captive cetaceans, it has been established that the main source of infection is dead fish that have not been well preserved (Geraci et al. 1966, Lauckner 1985, Suer \& Vedros 1988, Higgins 2000), but other likely sources are humans with erysipeloid, food preparation sites, opportunistic colonization of wounds, and flying insects serving as vectors between contaminated areas (Wood \& Shuman 1981). For these reasons, most cases occur in captive animals (Seibold \& Neal 1956, Geraci et al. 1966, Medway \& Schryver 1973, Thurman et al. 1983, Buck \& Spotte 1986, Bossart \& Eimstad 1988, Kinsel et al. 1997, Dunn et al. 2001). Seibold \& Neal (1956) described the first case of erysipelas in captive cetaceans. More recently, Chastel et al. (1975) reported the first case in a beached pilot whale, Young et al. (1997) reported the first case in a wild killer whale, and Boseret et al. (2002) described the first case in a harbor porpoise.

\section{MATERIALS AND METHODS}

On 14 July 2010, an adult female bottlenose dolphin stranded alive on the Mediterranean coast of Valencia (Spain). The clinical signs were froth from the blowhole and rales upon lung auscultation. A blood sample was collected by venipuncture on a vascular bundle of the tail fluke. On gross examination, the blood was abnormally dense and dark. The animal died on the beach several minutes after stranding.

The total length of the animal was $294 \mathrm{~cm}$, and radiological analysis of the pectoral flipper revealed epiphyseal ossification of the growth plates of the radius and ulna bones, which correlates well with sexual maturity (García-Párraga et al. 2011). We estimated the age of the dolphin to be between 20 and $30 \mathrm{yr}$, by comparing the radiographs to others from captive animals (data not shown). The animal showed noticeable breast development and galactorrhea, suggesting that it was a lactating female.

Samples of kidney, lung, skin, and brain were preserved in formalin and processed by conventional histological techniques, sectioned at $5 \mu \mathrm{m}$, and stained with hematoxylin and eosin.

Skin, brain, and lung were harvested under aseptic conditions for microbiology. Tissue samples were cultured on Columbia blood agar plates (bioMérieux) and incubated for $48 \mathrm{~h}$ at $35^{\circ} \mathrm{C}$ under both aerobic and anaerobic conditions. Biochemical identification was performed using the commercial API Coryne 2.0 system (bioMérieux) according to the manufacturer's instructions. Pure and heavy bacterial cultures were obtained from skin and brain.

\section{RESULTS AND DISCUSSION}

The blood analysis showed hematologic and biochemical abnormalities, including dehydration, leukocytosis $\left(48600\right.$ leukocytes $\mathrm{\mu l}^{-1}$ ) characterized by a neutrophilia (48200 neutrophils $\mu^{-1}$ ) and elevated 


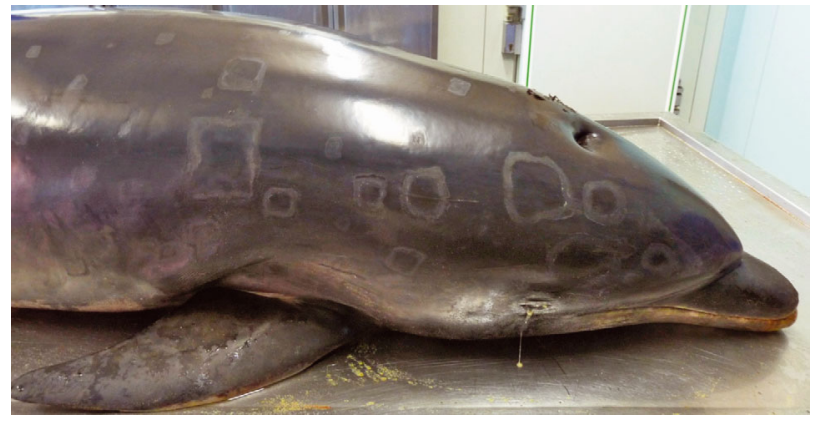

Fig. 1. Tursiops truncatus. Rhomboid-shaped skin lesions observed during external examination

levels of bilirubin (4.38 $\left.\mathrm{mg} \mathrm{dl}^{-1}\right)$ and increased alanine aminotransferase $\left(382.3 \mathrm{U} \mathrm{l}^{-1}\right)$, aspartate aminotransferase $\left(1449.3 \mathrm{U} \mathrm{l}^{-1}\right)$, lactate dehydrogenase $\left(1631.3 \mathrm{U} \mathrm{l}^{-1}\right)$, and creatine kinase $\left(404.7 \mathrm{U} \mathrm{l}^{-1}\right)$. Compared to reported normal ranges, these values are consistent with liver damage (Bossart et al. 2001).

External examination revealed colorless, raised, 1 to $8 \mathrm{~cm}$ long, rhomboid-shaped skin lesions with well-defined edges along the entire body surface (Fig. 1). Additional necropsy findings included stable white froth in the trachea, pulmonary congestion, abnormally thick and rough pleura with adhesions, edematous and congestive superficial cervical and tracheobronchial lymph nodes, red-tinged, clear urine (possible hematuria), and severe brain congestion. Histopathology revealed multisystemic intravascular bacteria (Fig. 2).

The microorganism isolated from the bacterial cultures obtained from skin and brain was a Grampositive, catalase-negative, facultatively anaerobic rod-shaped bacillus. The biochemical profile was identical to Erysipelothrix rhusiopathiae.

The gross and microscopic findings, as well as agonal clinical chemistry and bacteriology results, were consistent with those reported for Erysipelothrix rhusiopathiae septicemia in cetaceans such as captive bottlenose dolphin, spotted dolphin, Indo-Pacific bottlenose dolphin, Pacific white-sided dolphin, and Beluga whale (Seibold \& Neal 1956, Geraci et al. 1966, Thurman et al. 1983, Kinsel et al. 1997).

To our knowledge, this is the first reported case of Erysipelothrix rhusiopathiae septicemia in a freeranging bottlenose dolphin.

Acknowledgements. This work was supported by a collaborative agreement between Conselleria de Infraestructuras, Territorio y Medio Ambiente of Valencia, the Oceanographic Aquarium of the Ciudad de las Artes y las Ciencias of Valencia, the VISAVET Center of Com-

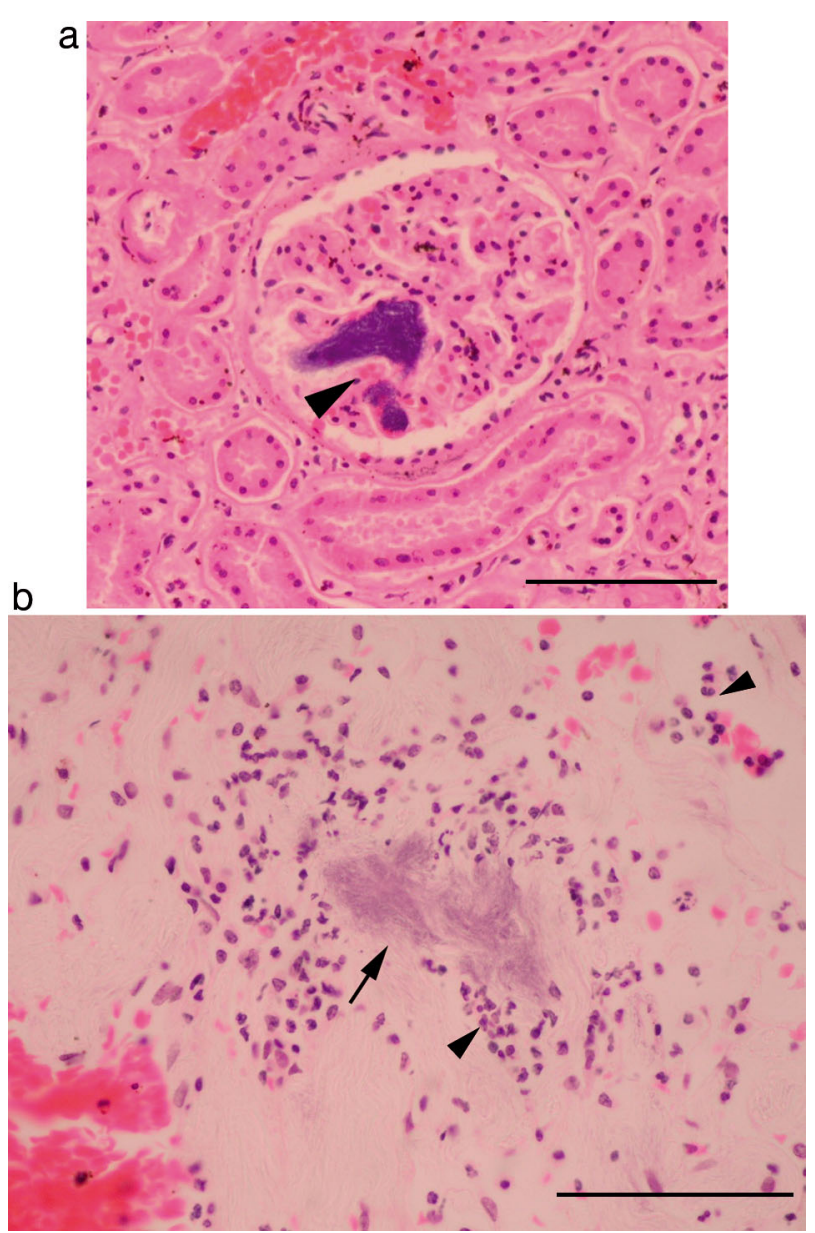

Fig. 2. Tursiops truncatus. (a) Histological kidney section showing intraglomerular bacterial emboli. (b) Presence of bacterial infection in connective tissue (dermis, arrow) associated with many neutrophilic cells (cellulitis, arrowheads). Hematoxylin and eosin $(400 \times)$. Scale bars $=50 \mu \mathrm{m}$

plutense University of Madrid, and the Pfizer Foundation. We thank the Institut Cavanilles de Biodiversitat i Biologia Evolutiva, University of Valencia, for collaboration on necropsy procedures.

\section{LITERATURE CITED}

Boseret G, Jauniaux T, Mainil J (2002) Erysipelothrix rhusiopathiae infection in stranded harbour porpoise and harbour seal. In: Erken AHM, Dorrenstein GM, Dollinger P (eds) Proc 2002 Eur Assoc Zoo Wildl Vet Annu Meet, Van Setten Kwadraat, Houten, p 15-17

Bossart GD, Eimstad E (1988) Erysipelothrix vesicular glositis in a killer whale (Orcinus orca). J Zoo Anim Med 19: 42-47

Bossart GD, Reidarson TH, Dierauf LA, Duffield DA (2001) Clinical pathology. In: Dierauf LA, Gulland FMD (eds) Handbook of marine mammal medicine: health, disease and rehabilitation, 2nd edn. CRC Press, Boca Raton, FL, p 393-420 
Brooke CJ, Riley TV (1999) Erysipelothrix rhusiopathiae: bacteriology, epidemiology and clinical manifestations of an occupational pathogen. J Med Microbiol 48: 789-799

Buck JD, Spotte S (1986) Microbiology of captive whitebeaked dolphins, Lagenorhynchus albirostris, with comments on epizootics. Zoo Biol 5:321-329

Chastel C, Masure O, Balouet G, Laban P, Lucas A (1975) The student, the cetacean and swine-fever: a minor epidemic after dissection of a globicephale. Nouv Presse Med 4:1803-1805

Dunn JL, Buck JD, Robeck TR (2001) Bacterial diseases of cetaceans and pinnipeds. In: Dierauf LA, Gulland FMD (eds) Handbook of marine mammal medicine: health, disease and rehabilitation, 2nd edn. CRC Press, Boca Raton, FL, p 312-319

García-Párraga D, Schmitt TL, Jensen E (2011) Use of radiographic parameters for age estimation in bottlenose dolphin (Tursiops truncatus). In: Mazzaro L (ed) Proc 42nd Annu Conf Int Assoc Aquat Anim Med. Omnipress, Las Vegas, NV, p 110-111

> Geraci JR, Sauer RM, Medway W (1966) Erysipelas in dolphins. Am J Vet Res 27:597-606

Higgins R (2000) Bacteria and fungi of marine mammals: a review. Can Vet J 41:105-116

Hunt TD, Ziccardi MH, Gulland FMD, Yochem PK, Hird DW, Rowles T, Mazet JAK (2008) Health risks for marine mammal workers. Dis Aquat Org 81:81-92

Kinsel MJ, Boehm JR, Harris B, Murnane RD (1997) Fatal

Editorial responsibility: Michael Moore,

Woods Hole, Massachusetts, USA
Erysipelothrix rhusiopathiae septicaemia in a captive Pacific white-sided dolphin. J Zoo Wildl Med 28: 494-497

Lauckner G (1985) Diseases of Mammalia: Pinnipedia, Vol IV. In: Kinne O (ed) Diseases of marine animals. Biologische Anstalt Helgoland, Hamburg, p 695-707

> Medway W, Schryver HF (1973) Respiratory problems in captive small cetaceans. J Am Vet Med Assoc 163: 571-573

Seibold HR, Neal JE (1956) Erysipelothrix septicaemia in the porpoise. J Am Vet Med Assoc 1956:537-539

Suer LD, Vedros NA (1988) Erysipelothrix rhusiopathiae. I. Isolation and characterization from pinnipeds and bite/abrasion wounds in humans. Dis Aquat Org 5:1-5

Thurman GD, Downes SJ, Fothergill MB, Goodwin NM, Hegarty MM (1983) Diagnosis and successful treatment of subacute erysipelas in a captive dolphin. J S Afr Vet Assoc 54:193-200

Wang Q, Chang BJ, Riley TV (2010) Erysipelothrix rhusiopathiae. Vet Microbiol 140:405-417

Wood RL, Shuman RD (1981) Erysipelothrix infection. In: Davis JL, Karstad LH, Trainer DO (eds) Infectious diseases of wild mammals, 2nd edn. Iowa State University Press, Ames, IA, p 297-305

Young JF, Huff DG, Ford JKB, Anthony JMG, Ellis G, Lewis RL (1997) First case report: mortality of wild resident killer whale (Orcinus orca) from Erysipilothrix rhusopathiae. In: Lewbart GA (ed) Proc 28th Annu Conf Int Assoc Aquat Anim Med. Harderwijk, p 70-74

Submitted: July 4, 2011; Accepted: September 6, 2011 Proofs received from author(s): November 12, 2011 